\title{
A CONCEPTUAL REVIEW OF THE EFFECTS OF TRADE PROTECTIONISM ON MARITIME ECONOMICS AND LOGISTICS
}

\author{
ALI UMAR AHMAD*, JAGAN JEEVAN AND SITI MARSILA MOHD RUSLAN \\ Faculty of Maritime Study, Universiti Malaysia Terengganu, 21030 Kuala Nerus, Terengganu, Malaysia
}

*Corresponding author: Umarahali204019@gmail.com

http://doi.org/10.46754/jml.2021.08.001

\begin{abstract}
In the last three decades, in particular, freight and container transport have grown rapidly worldwide. Protectionism, economic growth and the rising global economy have grown tremendously, and container transport has suffered adversely as a result. The issues facing the environment, economics and culture with regards to the sustainability of maritime logistics or transport must be considered. The trade-offs from direct cost of transport and credibility differ according to the trade in the country's goods and logistics, which can reduce potential to diversify among temporary and value-added products in developed countries'. This study aims to conduct a conceptual review of the effects of trade protectionism on logistics transition, port composition, and economic growth. Based on this, this study will propose a framework in which protectionism, logistic transition, port composition and economic growth research can more effectively utilized. However, effects of trade protectionism on logistic transition, port composition, and economic growth, should be further examined using the proposed growth models.
\end{abstract}

Keywords: Economic growth, logistic transition, port composition, trade protectionism

\section{Introduction}

Freight and container transportation have grown rapidly over the last three decades on a global scale, in line with economic growth and the growing global economy. However, protectionism and national fervour have increased enormously as of late, and the development of container transportation has been adversely affected as a result.

The issue of in maritime logistics and transport have to be considered in terms of its impact on the environment, the economy and culture, (Benedyk \& Peeta, 2018). The global economy is currently unstable, with most countries suffering from inflation, particularly landlocked countries, like Central African Republic, Afghanistan, Kazakhstan and Burundi. The costs of oil, food and other products which must be imported by these countries is high and are often delayed or take a long time to reach their destinations.

Additionally, domestic products are also difficult to export. Commerce is lower than in the neighbouring countries that have access to the sea. One of the reasons why some landlocked countries, all over the world, are among the poorest in the world is geography, the lack of access to proper trade routes, especially by sea. Road conditions are not the main reason for low productivity and expensive transport conditions (Duzbaievna-Sharapiyeva et al., 2019). This makes it impossible to solve all problems with an efficient infrastructure. Many researchers argue that all problems related to lack of access to the sea could be solved by efficient infrastructure.

The main problem is, as shown in the latest studies, the cargo delivery to these ports. It is important to note, among other concerns, that cargo delays at borders, pre-transport cartels with multiple customs and bribery processes artificially raise transport costs.

World trade is an important element in the global economy's economic growth. Countries rely on trade to increase domestic production in foreign markets, and trade is an important means of economic growth for emerging economies. The exporting countries' attractiveness and the needs of the importing countries are, of course, 
dependent on the volume of trade between the two countries ( $\mathrm{Li} \&$ Whalley, 2021). Where an importing country contains many potential sources of supply, it is important to determine the distance and related costs for the passage of the borders, transport of the goods and customs and duties imposed between trading partners.

Globalisation has united nations and increased trade so much that newer obstacles caused by different approaches to economic policy, which in some cases are highly restrictive have come up. Industrialisation has also allowed for nationwide growth, improved competitiveness and increased investment in efficient logistics models (Erokhin, 2017).

This theory leads to the assumption that the performance of logistics is key for global trade. The logistics of maritime transport is one that covers all aspects of trade including, production, trade, business growth, transport sector, information and communications technology, control of goods and transport and commerce equipment and the various entities involved in the whole process (Munim \& Schramm, 2018).

Therefore, world governments have no shortage of reasons for engaging in the development of more effective logistics systems; enhancing export and transport infrastructure competitiveness, promoting global trade, opening up new markets and boosting jobs in the services and supporting companies. World governments are also committed to mitigating environmental and social issues outside of port congestion, accidents, insecurity and pollution (Khan et al., 2019).

The globalisation of complex industrial production processes in the global supply chain has increased the importance of seaports. Port business is no longer restricted to cargo handling; in an international context, the provision of logistics services is a core business part (Wang et al., 2020). Logistics costs and the reliability of supply chains are the most important aspects of logistics performance. Poor logistics facilitation has a significant impact on the competitive advantage of a country, and
Arvis et al. (2007) gave insights in this respect. The time, cost and reliability of shipments, and predictability, is important in a world of "just-intime" production processes. The hedging costs of a company can be considerably high in terms of higher inventory maintenance requirement due to the poor reliability, predictable logistics services (Lin \& Qixiang, 2020). Trade between direct freight costs and reliability vary depending on the commodity and logistics performance of a country that can limit developed countries' potential to diversify from temporary and valueadded products.

Despite this importance the effects of port composition and logistics transition on trade and economy in a country have been largely ignored in available literature. A significant amount of research on improving energy-efficiency and using cutting-edge technology has been undertaken recently. Although there are many issues over the ongoing trade war between the United States and China and the spread of global protectionism, there is a lack of research on the matter. Tariffs and Non-tariff barriers to trade (NTBs) can severely damage the global economy. The global maritime trade increased by 2.7 percent and 2.8 percent respectively in 2018 and 2019 a more sluggish rate compared with the 4.1 percent seen in 2017 , but it was projected to increase by 3.4 percent from 201920024 according to United Nations Conference on Trade and Development [UNCTAD] (2020).

However, UNCTAD (2020) seems optimistic, assuming that, although taking into consideration a number of downside risks in trade tensions and protectionism and Brexit (the United Kingdom's withdrawal from the European Union) the existing World Trade Organization (WTO) system will govern global trade. The combined effects of high tariffs and NTBs on world port freight and containerized global port operations are not taken into consideration.

The G2 makes up 40 percent of the world's gross domestic product (GDP) and 22.6 percent of world trade, which are the key countries of the global value chain (GVC). The recent 
tariff war between the US and China has had huge repercussions on international trade and logistics demand. These adverse effects will be amplified with respect to tariffs and NTBs at the same time.

Meanwhile, following successful cases like Singapore, Hong Kong, Shenzhen, and Dubai, some countries are planning to develop regional port centers to name a few and expect a further improve their economies as new services markets open up.

The development of transhipment and effective transport networks will help this. The relationship between port and city has nevertheless changed and city structure is not important any longer to explain the intensity and spatial distribution of maritime transport networks (Yudhistira \& Sofiyandi, 2018). Jaffee (2019) argued that the economic development potential of the hub port development is less than most available literature has proposed. Due to structural changes in the global shipping industry, the harbour's performance forecast or its economic contribution is not as certain as planners expect. The shipping industry has also suffered adversely from the demolition of the shipping conference system in 2008 and the global financial crisis in 2009 (Munim \& Schramm, 2017).

Economic growth has moved to new economic sectors, requiring investments in various location factors, high quality of life and the attractive functioning of a town centre. Therefore, it is important to understand how far ports affect the national or regional economy before spending millions of dollars to develop or expand port composition. Therefore, this study aimed to conduct a conceptual review of the effects of trade protectionism on logistic transition, port composition, and economic growth.

This paper is organised as follows. The following section discusses the conceptual literature under review. The next section discusses a proposed conceptual framework, and the final section discusses the findings and conclusions drawn.

\section{Conceptual Literature}

As a result of trade liberalisation under the WTO's multilateral trading system, the world has experienced rapid trade and economic growth and protectionist trade policies are now spreading across the globe. Thus, increased trade tensions have hampered world trade. Protracted trade disputes will cause the world economy to slow periodically. The following sub-section discusses the concepts of economic growth, trade protectionism, logistic transition, and port composition.

\section{Economic Growth}

The large disparity in growth experiences in various countries in recent history has had an astonishing impact on global economic growth. Several parts of the world, such as Western Europe and the US have witnessed persistent economic growth for more than a century. These countries have a very rich culture. However, in absolute terms if wealth is measured as per capita income (GDP per person) the result is not always true (Briguglio, Vella, \& Moncada, 2019).

At present, there are many nations with large sections of their population living near the subsistence, poverty line. However, a set of nations that were poor around World War II have since managed to reach an even higher rate of economic growth than developed nations of the western world. Defining this economic growth in one model has proven difficult. Some models clarify the economic development of the now developed countries, but most of them ignore the reasons why most of the world is and has remained poor.

For industrialised countries, models which seek to explain the difference between development and developed are more efficient to reproduce the economic growth facts (Petrakis, 2020).

Convergence is the key feature of this model, used more and more frequently as a tool to form and test hypothesis in recent years. The higher the projected growth rate, the lower the initial 
level of real gross domestic product per capita. If all the economies of the world would of course be the same, except for their start of capital, then convergence would be in full use; that is, poverty would appear to rise per capita faster than in wealthy economies. Conversely, in the real world given the differences in the economies in terms of their levels of savings, having children, access to technology, willingness to work and government policies, the convergence force only has a small impact. If per capita initial GDP is small in terms of long-term or stable position, the economic growth rate appears to be strong if it starts well below its target position. For instance, a developing country, which also has a small long-term position, cannot grow rapidly due to its risks in terms of public policies, or a low savings rate (Cavallaro \& Villani, 2021).

In the neoclassical model the declining returns on capital is derived from convergence property. Economies with lower equity per employee (about their long-term equity per employee) are inclined to increase returns and higher economic growth rates. Convergence is conditional since the stable state levels of capital and per worker rely on the neoclassical model of saving propensity, population growth rates and the role of production functions in different economies.

Recent extensions to the model indicate that other causes of country-wide fluctuation need to be included, in particular government policies on domestic and foreign market distortions, security of ownership rights and consumption levels. The theory of capital can be usefully extended to include human capital in educational, health and expertise from natural resources in the neoclassical system (Lucas, 1988; Rebelo, 1991; Caballe \& Santos, 1993).

The economy leads to a stable ratio between human and physical resources, but the ratio in an initial state may differ from its long-term value. The scale of this leaving has an effect on the per capita performance rate. A nation which begins with a very high ratio of human to physical capital (perhaps as a result of a war in which capital is mostly physical) tends to develop quickly, since physical capital is more sensitive to rapid expansion than human capital. The strength of support is to promote the adaptation of international technology through a strong human capital commitment (Nelson \& Phelps, 1966; Benhabib \& Spiegel, 1994). This aspect implies a product of interaction whereby the rate of economic growth of a country is more responsive to its initial per capita production, the bigger the initial human capital stock is.

Another prediction of the neoclassical models is that human capital, when expanded to include physical capital, would eventually cease to rise per capita in the absence of continuous advances in technology. The consequence of this calculation similar to the Malthus (1798) and Ricardo (1817) is that the returns to the total concept of capital have been reduced. Longterm figures for some countries have shown that positive per capita growth rates will continue for more than a century, but there is no strong decline in this rate of economic growth.

Economic growth theorists of the 1950's and 1960's acknowledged and covered up this modelling void by the belief that unexplained (exogenous) means accompanied technological advance. This device will solve the theory by maintaining the forecast of conditional convergence with an optimistic and perhaps steady per capita growth rate in the long run (Ziesemer, 2021).

\section{Trade Protectionism}

Some economists predicted that freedom of trade would reign supreme before the public if the results of an election analysis became widely known. These estimates depended on presumptions of public interest so regularly overwhelmed by financial arrangements or innocent political theory that any specific shields were crushed in light of the fact that a vast dominant part of society would lose such protectionism. 
This is a function and consequence of the public-choice "rent seeking" theory ( $\mathrm{Li} \&$ Whalley, 2021), where "rent-seeking" means seeking to increase one's share of existing wealth without creating new wealth.

There are different expectations regarding the rent-seeking model of public choice The model highlights expensive information and the free riding incentives that many voters indicate, whether or not they vote rationally.

Concentrated efforts by well-organised producer groups encourage them to be highly active politically and to influence the political process ( $\mathrm{Li} \&$ Whalley, 2021). This process is a direct consequence of the prevalence of protectionist tariffs, quotas and voluntary export restrictions (VERs). This interpretation of public choice gives a strong insight into trade policy formation.

Despite the importance of such insights, such applications of simple rent seeking commercial policy theory has serious problems.

The current challenge for public choice analysis, which takes the same principles that economists use to analyse people's actions in the marketplace and applies them to people's actions in collective decision making, can explain protection the theory dictates. This is why trade protectionism is less widespread (Erokhin, 2017).

Although today the US has many formal and informal trade obstacles, the levels of protection offered by the Smoot-Hawley Tariffs in the 1930 ' are relatively small. For many other nations too, the story is identical.

The quest for information has prompted a more extensive assortment of issues being tended to by general society and political specialists, similar to the job of thoughts and establishments, the leader objectives, and the improvement of gatherings of interest against insurance. Most of the early business policy analysis took the country as the fundamental analysis unit and focussed on calculations of the so-called optimum tariff, so that the trade barriers could be used by a country with market power to improve trading conditions (Cheong \& Tongzon, 2018). Most studies looked at how to maintain the balance between the benefits and national protectionism's standard cost of efficiency.

Retaliation decreases the scope for profit, but it remains positive sometimes. Such optimal tariff models were used to justify bilateral agreements such as GATT in terms of damping the incentives of nations to play such games. However, this optimal modelling of tariffs offers little insight into the real formulation of trade policies or the best design of institutions to curb protectionism except in cases of economic warfare (Olabisi et al., 2021). A much greater power of reasoning seems to come from standards for rent and the contemporary mercantilism models, which national leaders believe are good for the national economy and/ or national power and security, trade surpluses are good for the domestic economy.

Of course, the argument for tariffs, it is true that protectionism would not improve the trade balance, as importation tariffs depreciate the currency or extend net exportations, under a flexible exchange rate or under the specie-flow mechanism, which explain how trade imbalances can be automatically adjusted under the gold standard, in the long run. Obviously, both the rent-seeking, mechanism and bad economics are tied together in order to exploit mercantilist ideological and economic inefficiencies for the benefit of interest groups (Curran \& Eckhardt, 2018).

In the literature on international political economy, a unified rational actor or a billionball view of nations also characterises the traditionally dominant school of thought. This approach, is killed as realist or modern mercantilist, focuses on the search for power and security in the nations and the role of international power structures in shaping international outcomes. 
The idea of such views to France, Japan and many of the newly industrialised countries is widely recognised. However, trade protectionism does not always include foreign policy and national security goals.

In the United States during the post-war era, a strong force behind Democratic and Republican administrations in their attempts to foster trade liberalisation, and to combat protectionism, was the notion that liberal trade policies helped promote American foreign policy and national security concerns (Park, 2019). These foreign-policy issues and lessons from the Grand Depression were combined to encourage institutional reforms aimed at treating commercial policy as an aspect of foreign policy, not just domestic policy and strengthening the executive branch's hand in setting trade policy in respect to Congress.

These are the main reasons why US trade barriers gradually decreased during the first few decades after World War II (Burtless, 1995; Hathaway, 1998). The slowing of the US trade liberalisation movement can, Willett (1995) argues, be explained by the increase in pressure from interest groups on both national security issues and the weakening powers of Congress. While the realistic interpretation sees the rise in US protectionism as a result of strong government, Willett sees the process as a weakening of the state's authority relative to domestic social pressures, de Vries (1967), which argues that the resources absorbed in the lobbying for protection could outweigh the cost of protection itself, which is an important early contribution to a public choice approach to protectionism.

The same theme is developed by Krueger (1974), who says that protection shapes the resources sacrificed in the import license competition. She emphasizes, however, the important idea that government constraints on economic activities in many economies are all-encompassing facts of life, which give rents, and people frequently compete for rents. Norgard (1992) sees that the utilisation of assets that are harming somewhere else may, while not straightforwardly profitable, by implication upgrade government assistance in mutilated monetary exercises, for example, campaigning for assurance, carrying and going after import licenses.

Krueger (1983) stresses that rewarding rent-seekers undermines the public's confidence in market fairness, which leads to greater government intervention which in turn leads to even more rent-seeking, forming a vicious cycle. The readily available literature by Markussen et al. (1995), and we build on their debate. The notion that public officials adopt policies to increase the likelihood of their re-election is based on many models of public choice. Suppose the electorate is organised to the level of protectionism, which they endorse in one line in an electorate.

The bill with the most support is the one that appeals to the median electorate if the level of protectionism is to be determined by referendum. If a parliament is to vote, politicians that support the median voters' level of protection tend to be elected. There are a few who own a lot of capital and those who do not have a capital in most countries, but all electors have the same amounts of factor work. The median voter is also likely to vote in line with labour interests. The theorem of Stopper-Samuelson states that when work and capital are both mobile between different sectors and certain other requirements are met, work is either benefited or protected depending on whether work is the scarce or abundant factor of the country.

The empirical implication is this, while protection is dangerous to any countries which are too small to influence world prices, in the sense that free-trade profit is likely to make up for and improve losses. The empiric implication is that countries which lack labour are likely to have higher rates in average than countries with an abundance of labour.

The overlapping Gokcekus and Tower (1998) generation model produces similar results. They discover, if a labor scarce country liberalises, because all people have a 
comparable structure of capital formation over their entire lives, that they are capitalists that are already accumulating assets and are either gaining or losing the youth who are workers now but are capitalists later in life. When most people are young, trade agreements in the labour scarcity economy can be opposed, because it boosts the entire economy. And although trade liberalisation alone is politically difficult, the law with the most appeal should include freedom of trade for a country in front of fixed international prices through the combination of a commercial bill with an income redistribution bill.

Moreover, since the world prices are not set, free trade, together with the necessary transfer between nations, is the cooperative agreement with other countries that should meet the widest approval (Copeland et al., 1989). The protectionism should be restricted through these mechanisms.

\section{Logistic Transition}

Logistics research may be characterised as a systematic and objective search, analysing and identifying data relating to and resolving a logistical problem. A lot of logistics research is carried out on the premise that there are connections between a specific path and logistical performance (or effectiveness). Unfortunately, it is frustrating to draw broad inferences from the work done, as performance was defined in literature in various ways. For researchers in any management field, defining performance is a challenge because organisations have many and often divergent goals (Longaray et al., 2018). Some of them identify profit objectives. Others may choose customer service or sales maximization objectives. The tasks to select and produce suitable measures for the selected definition are often difficult. Each of them has its strengths as well as its related weaknesses (e.g., net income or accounting figures) and "soft" measures (for example, customer satisfaction ratings).

Logistics has developed into a strategic, cross-function and global discipline from a simple traditional transport function (Moons et al., 2019). Today's highly fragmented value chains have become a prerequisite for the supply of production material for factories and the distribution of finished goods in the warehouses and shops. The growing effect of logistics on the success of a company and its economic growth emphasises the importance of future schemes in this area. The supply of food, everyday goods, books, education material and medicine to the world's population has become one of the main issues to promote economic growth in emerging and developing countries, particularly in rural areas (Aharonovitz et al., 2018).

How logistics performance is affected by supply chain relationships. The international journal of logistics management.). In addition, the specialization of logistics system has evolved how to understand logistics aspects and the strong conviction that logistics helps to achieve economic wealth and cost savings. Disaster relief, humanitarian assistance and provision of refugee camps are now key areas for professional logistics. As a result, logistics' overall importance grows.

Therefore, new challenges in the field require innovative and updated approaches (Wang, 2018). The importance of management of logistics has been increasing in different areas since the logistics developed since the 1950s due to the trend of nationalization and globalization of recent decades. Logistics helps industry optimise existing manufacturing and distribution processes based on equal resources by managing techniques to promote efficiency and competitiveness of companies (Morgan et al., 2018).

There has not been sufficient research into the role of the logistics system in minimizing the environment effect of industries. The link between operational efficiency and environmental aspects is particularly important to understand. Both are the result of a number of strategic and operational decisions made within the company. In addition, logistical purposes can improve the company's level of performance and can influence the level of performance of complementary corporate resources. 
By fulfilling customer delivery requests, Logistics creates value. The performance of the logistics industry shall therefore indicate the ability of the organization to supply goods and services in the amount needed by customers, if required at reasonable cost. Performance in logistics can be regarded as a part of the broader organizational output concept (Kinra et al., 2020). The most ordinary exhibition in coordination depends on the formation of time and spot convenience while in seven- $R$ equation the characters of the item or administration offered by an association lead to the improvement of utility administrations through logistics exercises.

It refers to the ability of the organization to provide the appropriate product at the proper place in the correct condition and at the right price, and to the right information at the right time (Tsapi, 2020). The degree of efficiency, efficacy and differentiation in the performance of logistics operations is determined as logistics performance (Lin \& Qixiang, 2020).

The logistics function in its entirety should aim at reducing the ratio of resources to derived results (efficiency), achieving predefined objectives (effectiveness) and gaining superiority over the competitors (differentiation). A transport system, which connects separate activities, is a key element in the logistics chain. Carriage accounts for $1 / 3$ of the logistics cost and transport systems greatly affect the logistics system performance. The transport of goods to the final consumers and returns is required throughout the production process from manufacture to delivery. The only advantages would be good coordination between each component (Hammes et al., 2020).

Logistics could not fully benefit from its benefits without well-developed transport systems. A good logistics transport system will improve logistics efficiency, minimize operating costs and enhance the quality of service. Improving transport systems requires the efforts of public and private sectors alike. A well-operated logistics system could boost both government and business competitiveness.
In trade policy, logistics and transport play an increasingly crucial role. The Logistics Performance Index (LPI) analyses customs procedures, logistical costs and infrastructure quality differences among countries in the field of interisland and maritime transport.

\section{Port Composition}

The ports are regions that are connected by waterways to a sea, sea or river and are regarded as entities. They are equipped with all types of infrastructures and technical equipment to handle their type of load. Its fundamental function is to provide shelter to ships in a different way to facilitate the transport of goods from one way to another. It also functions as a node connection between land and sea and as a clear example of intramodality (Castillo et al., 2020). The seaports are working more and more as junctions from which imported goods are delivered in the hinterland and goods to be sent out of the hinterland are grouped together and loaded into ships.

Because the volume of goods to be carried to and from their port is rarely or never equal to the ability of an inland transport, and since the time of loading and unloading a navy does not necessarily correspond to the loading time of the inland mode, the port's distribution function is the storage of goods (de-Lima et al., 2018). All these approach regards the position of a port in the logistical chain, while a port is also a chain comprising consecutive connections in more detail (ship unloading, storage, loading transport, storage transport, and hinterland loading). Ports thus compete among themselves to be part of those global logistic chains, which means chain systems compete with chain systems from an analytical point of view.

Robinson calls, inter alia, for a change of paradigm to regard ports as components integrated into value-driven chains (Lee et al., 2018). In view of data availability, as outlined in this article, the port competition model follows the logistic chain approach as far as possible. In the North-West Europe port range, 
competitiveness between ports is very different depending on the freight type. Crude oil, depending on the equipment at the ports and the access to inland waters and pipelines, is the most captive cargo (Taljaard et al., 2021).

The captivity classification is followed by other bulk products such as mineral oil or iron and ear and scrap. The survey places the whole range of other general cargoes, as this is a very various category and there is different captivity. At the bottom end of the captivity ranking are agribulk, containers and roll-on and roll-off charges. The example of the Port of Rotterdam is a hinterland comprising Europe's industrial centres, with the North Sea port of Hamburg, Bremen in North Germany and, in particular, Antwerp in Belgium as its primary rivals for this hinterland. The competitive position of ports, however, cannot be divided into one status, since they do not compete in a single market, but in a large number of markets with different characteristics as result of differences between place of origin, destination and type of cargo (Zhao et al., 2021). For example, the general statement that the port of Hamburg and Rotterdam is competitive does not mean it is correct.

More detailed definitions of the market are necessary, since container transports to and from the Dortmund area are highly competitive in ports Rotterdam and Hamburg. In the early instance it is our intention to increase the scope for modelling to simulate competition with other port areas or alternate routes among us, but we want to expand the scale of modelling (Kravets et al., 2021). The rapidly developing ports in South Europe such as those in Italy are examples of such extension. In some areas of their hinterland, such as Northern Italy, France, Austria and Switzerland, these ports become greater competition in north-western European ports.

The Trans-Siberian railway (TSR) is another potential threat to North West ports as it bypassed the maritime route, for example the Indian Ocean and the Mediterranean Sea and may serve as an alternative for shipping container between Asia and Europe (Liu, 2020). This railway is a potential threat to North West European ports. Ports and governments have reacted with major investments to attract these container flows to the global container market growth and more competitive conditions. These investments cover all parts of the transportation chain, sea access, port capacities and productivity and inland transportation (Balliauw et al., 2019).

In order to use the scale innovations in most ports in the maritime industry, often through government aid, it is important for ships over 8000 and recently 13,500 TEUS to deepen their maritime accessibility (ship Emma Maersk). This continued growth in ship size increases the competitive position of ports, depending on natural nautical conditions and investment levels in maritime access. The deepening and expansion of the Scheldt access river to Antwerp harbour is an example of this investment. The trend was that shipping lines are attempting to outperform their competitors by deploying bigger ships driven by a one-way focus on sea costs.

However, future trends in ship size are somewhat unclear, given the limits of the increases in scale and a shift from pure shipping to integrated logistics solutions, including port handling and inland transport. The ability of the free terminal is critical to attract new or expanded services and, as a result of private investment in terminal capacity, the container handling capacity was (and is expected to) increase quickly in the Le Havre-Hamburg range. The survey of port capacity is expected to double from 37 million TEU in 2005 to $70-80$ million TEU in 2020, which is part of the study covering Rotterdam, Antwerp, Bremen and Hamburg. This means that enormous investments are ongoing and prepared in terminal capacity. Hinterland transport and transport costs are an important element and hence an important competitive factor in logistics chain costs.

Ports are therefore very active in improving internal conditions for all forms of transport, in conjunction with regional and national governments. The hinterland of the port of 
Rotterdam, for example, has recently improved by expanding its internal options by building a ferrovia (railroad) between Maasvlakte 1 and Germany (the so-called Betuwe line; investment cost $€ 4.7$ billion). By reactivating the Iron Rhine railway link to Germany, the port of Antwerp has similar aspirations. These large investments in shipping, ports and inland transportation require the implementation of analytical tools, including a modelling of port rivalry. As we have seen, the flow of the port therefore depends not only on trade developments but on developments in the market shares of the harbours, and the use of the new infrastructure. It will include trade, destinations and freight, in ship sizes, in sea access, port capacity and productivity and inland transport, and in a competitive port modelling framework. This instrument enables investment to be evaluated in various economic and maritime scenarios, with the impact of competitive ports being considered.

As noted earlier, the types of classification studies are based on the different characteristics of each facility and enable them to meet their needs.

At that point characterise the accompanying eight port sorts: Deepwater Seaport is viewed as a deep-water port, which, in both the passageway channel and the terminal region, is over $13,72 \mathrm{~m}$ in draft (mean by the vertical separation from the water surface to the ocean level), incorporates all ports, whose front land (deep-water territory of association) is arranged inside the sea region, or in the sea zone, inside this degree; Waterway Port: all ports on one bank of the stream, independent of profundity, will be viewed as foundation of stream, Port reach will incorporate establishments utilised for cargoing and dumping of products and protected water outside, albeit not carefully thought to be port.

A dam built in this context, and these facilities provided for are marine or oceanic; "Pier, jetty or wharf," is a surge that must not always be protected from foreign waters. The overcoat can be done by means of a dam built for this purpose; "Port Terminal": while strictly a classification should be included by one of the above, it is necessary to determine that subdivision by the large number of such facilities in the world. There are also so-called "dedicated terminals."

Strictly speaking, it is not about ports, but simply terminals that always have the same material loaded or downloaded and therefore only the products they handle can be accessed by their facilities. Soybeans, coal and other minerals are the most frequently used terminals. The vast majority are solid bulk, while liquid bulk terminals such as oils, certain kinds of gases, etc. are also specialised; "Terminals offshore": these are facilities that are not on the coast and all the surface on the sea. Terminals are fully artificial companies whose area is specifically designed to accommodate the merchandise management equipment. devoted solely to deconsolidating the inbound cargo, and to consolidating the project cargo through the same canal by short sea shipping in their interior; "Canal": There are some ports that are not entirely river related. This is the case with the entrance to the marine and kilometres of rivers. This facility is in all cases connected by a single point to the sea or the ocean. This classification does not apply to installations built artificially or operating simply as ships passing through (like the Panama Canal or the Suez Canal).

Lack of certainty linked to the liberalization of trade also contributes to the explanation of why duties remain. It is easy to identify those who would be affected by liberalization. It is more difficult to recognize those who achieve better jobs by increasing opportunities in nontraded and export industries. Darlington et al., (1995) says the electorate tend to feel the easy to identify.

Therefore, governments should spend large sums to rescue a recognizable person, despite the fact that they would have used this money better to save the lives of many unidentified people through medical research. In the same way, as voters sympathize with obvious free-trade losers, there may be little political pressure to liberalize trade, but the cost of each job protected can be enormous. Experimental economics also shows 
(Marzi, 1998), that people tend to value their own higher than prospects. Both ideas propose the so-called status quo bias in relation to trade liberalisation policies. The conservative social welfare function of Corden (1974) strengthened this bias, which means that society promotes policies to prevent any significant group's fall in real income. As Aizenman and Marion, (1993) notes, this uncertainty may explain "why the return of democracy (pense in Pinochet's trade reforms in Chile) survives reforms introduced by an authoritarian regime against prevalent political sentiments." Further implications are that in boom times where revenues rise rather than recession liberalisation is more likely.

But Roll and Hayuth, (1993) for the counterargument that "a profound economic crisis relegates distribution considerations second behind economic issues, thereby allowing a timely administration to pursue trade reform in conjunction with macro-economic reforms." Public decision also provides a means of protecting the competing industry in imports between production subsidies, import tariffs and import quotas. The welfare loss for the protected industry against quotas per unit of protection is usually greater than for tariffs that surpass subsidies. Consumers should therefore classify the three policies in the order indicated. Home producers and protection seekers know that quotas are less visible than subsidies or tariffs and are thus likely to be above the other two quotas. Many who depend on government spending, income seekers, will probably prefer income tax to neutral quotas and they will both prefer revenue subsidies to those that absorb revenue.

Another alternative is import quotas and foreigners' quota rights. Some of them called VERs or "voluntary" import restrictions because foreigners limit exports "voluntarily" to prevent other forms of U.S. protection. VER's turn competitive foreign companies into monopolists when they are placed at the appropriate level. The perfect form of protection of these foreigners is a VER set at its optimum level. Such restrictions allow foreigners to act as a cartel and buy out foreign resistance to US protectionism by limiting sales to the US market and driving up prices (Nam, 1993). Finally, Krueger (1983) argued, as the latter have no Budget costs and are, thus, more likely to be excessive, that all forms of import substituting protection are inferior to export subsidies in order to encourage individual industries. Nader et al. (1993) are an elegant solution to why we do not end up in free trade or self-sufficiency.

He contends that the level of protection of the competitive import sector to the detriment of the remaining economies is a function of lobbying spending for both sectors. Each sector will use time, energy and money to balance the expected incremental cost and benefits of further lobbying and political pressure. It follows from Becker's logic that further increases in protection would result in the favoured sector's gaining less and less benefit compared with the costs incurred by the harmed sector, given the increase in protectionist policies. This reduces the extent of the former lobbying relative to the latter level, leading to a balance of protection. In reality, Nader et al., (1993) contends that the political system tends to produce effective results if lobbying is balanced. The political process also tends to select tariffs, different types of quotas and subsidies effectively. However, the political process is most likely to unite support towards forms of protection which are the best way of reaching the groups which are best able to move money seeking resources. It suggests that the authorities may be motivated to introduce a constitutional amendment in order to prevent the government from applying efficient policies (such as lump-sum taxes and subsidies) to redistribute revenue, because the option of inefficient policies may reduce rental costs.

Therefore, their model proposes a new way to distort policies as a political balance (Michaels, 1999). Trachtman, (1993) examine a related eleven issue. They create rigorous models showing that welfare can be improved under certain circumstances by forcing the government only to protect through a uniform tariff. However, uniformity creates a problem 
of free riders that decreases tariff lobbying incentives. Secondly, uniformity once again eliminates lobbying by those industries if the import-competing inputs are used. Lastly, consistency may force future government to restrict its efforts to redistribute revenue by using tariffs.

Irwin notes (ongoing) that the industrialised North East of the US wanted tariffs to protect producers in the early 1800s. The Western developing countries wanted tariffs to protect their revenue. However, the income seekers could gain enough political power to defeat free traders with protection seekers. But protectors don't always match income claimers because protectionists wanted the tariff higher than the maximum income, as Sykes, (1999) notes in the early US years, while income seekers wanted it below the level of maximum income.

The use of anti-dumping laws has become ever more significant in recent years. The US International Committee (formerly the US Tariff Commission) must find, in order for the anti-dumping duty to be activated, that imports have harmed the domestic industry and the US Department of Commerce must find that imports are priced in an unfair manner. Williams (1999) regrets that anti-dumping rulings are not transparent. They note that imports into the US may be considered "unfair" even though foreign companies make healthy profits from every sale in the country.

"Foreign companies which charge not merely higher prices outside of their own countries, but are also charging higher prices than their domestic rivals, still have 50 percent or higher dumping margins. In this instance anti-dumping has more to do with predatory pricing. Furthermore, anti-dumping policies have nothing to do with keeping trade "fair," except for the strongest supporters, lobbyists. It is merely another tool to increase the plaintiff's competitiveness with other companies,"

Anti-dumping policies have not got anything to do with being morally right or wrong. "Continued tinkering with anti-dumping statutes has sufficiently weakened the law that there is little real indication of harmful dumping before duties are imposed."

"A foreign company can almost ensure that anti-dumping duties will not apply if it charges in its export markets sufficiently high prices. The US International Trade Commission is using high-import penetration and low domestic jobs for inferno injury, which is a crucial prerequisite to winning an anti-dumping case, as a domestic industry may refuse to lower prices [and] may lay off more employees than expected.

Political pressure is important in the handling of anti-dumping complaints by the US International Trade Commission (USISC). Two supervisory committees of the House and Senate control the budget of the USISC, and three studies, as Fink, (1999) note, all find out that the industry of the supervisory districts receives better Commission treatment. Ramani (1996) discovered that the likelihood of an injury finding increases by around eight percent with another surveillance representative. In addition, the results are even more disastrous: "The US political action committee (PAC) donations to the 13 surveillance members also improve the chances for the industry to gain favourable subsidies, which indicate that political pressure is created not only through employment concerns but also through reelection funding issues."

Anti-dumping policies are an additional channel for economic rental distribution. Hartigan and Rogers (coming) discover an insider purchasing pattern in the two months preceding the filing of anti-dumping complaints, despite a ban on insider buyers from the US Securities and Exchange Board on the basis of material information not currently publicly available.

\section{Trade Protectionism, Logistics Transaction, Port Composition, Port Composition and Economics Growth}

Trade liberalisation under the WTO's multilateral trade system has resulted in global trade and economic growth, but protectionist trade policies are still expanding across the globe. As a 
result, increased international uncertainties have limited global trade. For a long time, economists have studied how trade policies affect economic growth. Protectionist strategies, according to empirical research based on data from the late twentieth and early twenty-first centuries, reduce economic growth (Eaton et al., 2016; Gygli et al., 2019; Andersen et al., 2020). Most reports show a strong association between tariffs and economic price ("tariff-growth paradox") in the late 19th and early 20th centuries (Lehmann \& O'Rourke, 2011; Schularick \& Solomou, 2011).

Modern economic theory holds that trade policy and economic management efficiency have a significant effect on a country's economic growth. Bown and Crowley (2014) investigated changes in trade policies of 13 WTO members using the negative binomial distribution (based on explanatory variables such as real GDP growth, changes in bilateral exchange rates, real GDP growth in partner countries, changes in the unemployment rate, and growth in bilateral imports (1995-2010). The 13 WTO members were Argentina, Brazil, China, Colombia, India, Indonesia, Malaysia, and Mexico.

They discovered that these countries' import controls are countercyclical, and that their trading strategies became more vulnerable to rapid swings in the actual exchange rate over time. Protectionist trends in foreign trade intensified after the 2008 financial crisis, according to Aggarwal and Evenett (2013), and international trade deals became more favoured. Many countries have revised their trade policies in response to China's increasing presence in foreign trade (where government participation in trade is still significant). Grundke and Moser (2019) used the Arellano-Bond GMM estimator to gather data on 93 classes of products imported from 167 countries into the US from 2002 to 2014 and found that non-tariff limits on imports had a negative impact on US exports. They say that the US has latent countercyclical protectionism and that non-tariff barriers have increased since the crisis.
Costa et al. (2019) investigated the impact of the pound sterling decline on trade, employment, and business training costs in the United Kingdom. They observed that the pound sterling fall resulted in lower salaries and lower recruitment costs for employers in industries where intermediate import rates rose. Alege and Osabuohien (2015) compiled equations for the dependency of exports and imports on the exchange rate, real GDP, money, and technology using data from 40 African countries for the period 1980-2008 and a partial-equilibrium relative price approach. They discovered that the number of exports and imports is not elastic in relation to the exchange rate using the panel cointegration test. In 107 countries around the world, Osabuohien et al. (2018) used a logistic regression model to look at the relationships between propensities for protectionism and metrics like economic growth, infrastructure progress, economic transparency (the ratio of net exports to GDP), and institutional efficiency.

The study found that the level of economic growth of a nation has no bearing on the application of trade restrictions. They claim that as institutions change, protectionist impulses will fade away. Another fascinating result of this analysis is that as a country's trade grows, so does its proclivity to defend itself. According to Kinzius et al. (2019), the number of non-tariff trade barriers is increasing in the developed world, and these limitations result in a 12 percent decrease in imports. According to Park (2018), the United States has been transitioning from "open trading" to "fair trade" since 2016. (which is the basis of high tariff barriers and the revision of trade agreements). He claimed that imposing high tariffs would result in higher consumer and export rates in the US, resulting in significant economic losses.

Protectionism, he believed, is a two-edged sword, even for the US economy. Northeast Asian economies, which are more reliant on export rates, would suffer significant losses as a result of such a scheme. Protectionist movements have been seen to delay global trade in studies by Lewis and Monarch (2016), Carstens (2018), 
IRC (2016), Constantinescu et al. (2015), Ojo and Alege (2014), and others.

The effect of logistics transition development on economic growth, on the other hand, is twofold: First, basic infrastructure serves as a supplement to wealth creation and growth of the private sector. The availability of public resources in logistics facilities, such as highways, airports, and seaports, helps the private sector expand by facilitating the effective delivery of goods and services (Aschauer, 1989). Furthermore, logistics productivity is a driver for crossborder trade transfers since businesses will save time and money by optimising their production processes and synchronising their details. Changes in transportation prices, in particular, influence the volume and scope of international trade (Behar \& Venables, 2011).

The effect of public capital on private capital has been used to study the relationship between infrastructure construction and economic growth. It is widely assumed that public capital, such as highways, airports, and seaports, boosts private sector competitiveness by facilitating the flow of goods and services across national and international borders. According to Aschauer (1989), there is a clear and optimistic relationship between public non-military capital spending and private sector production in the G7 developed countries. Brox and Fader (2005) and $\mathrm{Fu}$ et al. (2018), respectively, documented similar findings for Canada, Belgium, and New Zealand. Miller and Tsoukis (2001) discovered that government spending on public capital has a positive effect on economic development in 44 countries across Europe, Asia, the Middle East, and Latin America.

Another large body of research focuses on the importance of logistics networks in international trade cooperation. Lai et al. (2019) looked at the interaction between foreign trade and logistics networks in Association of Southeast Asian Nations, (Asean) countries and discovered that trade liberalisation and transportation growth complement each other. Çelebi (2019) looked at the impact of logistics networks on trade facilitation based on income levels. Low-income economies, in particular, have benefited from improved logistics efficiency as a result of increased exports.

Global transportation networks, according to Halaszovich and Kinra (2018), foster foreign trade by lowering distance costs. They specifically mentioned the value of port facilities in facilitating foreign trade. Wessel (2019) found that developing transportation networks boosts trade for a specific mode of transportation, as well as multimodal trade between European countries. Though logistics transition is regarded as a driving force for regional economic growth, the positive relationship has drawn growing attention to emerging and underdeveloped economies.

However, there is no consensus on the importance of the economic effect or the causality path. For example, Lall (2007) discovered that expenditures on transportation and communications networks are significant drivers of economic growth in Indian states. Calderon and Serven (2010) found a close connection between transportation infrastructure and economic growth in African countries (Kodongo \& Ojah, 2016; Fosu et al., 2012). Other experiments, on the other hand, propose a faulty link or a reverse causal interaction. According to Kustepeli et al. (2012), there are no long-term partnerships in Turkey between highway maintenance spending, economic development, and foreign trade. In India, Maparu and Mazumder (2017) discovered a causal connection between economic growth and transport systems.

However, many studies have justified investment in transportation infrastructure as a stimulator of a country's or region's economic development, most economic impact studies on seaborne trade have concentrated on a single seaport or region, making a straightforward image of how seaborne trade benefits global economies inaccessible. Kinsey (1981) concluded that, in the case of the Port of Liverpool, the importance of ports on the local economy was waning, with less workers directly relying on the port at the time. The role of ports on the local economies 
was further reduced because British ports were no longer large employers and the industrial inter-related complexities were no longer present (Gripaios \& Gripaios, 1995)

Various latest studies, one in South Korea (Jung, 2011) and the other in China (Deng et al., 2013), both argue that ports are having a negative impact on the economy. Jung (2011) found that between 1990 and 2008, the direct port job generation impact per billion Korean won decreased by 87.5 percent in South Korea. About the fact that seaborne trade has had little substantial effects on economic development, Deng et al. (2013) discovered a significant positive relationship between regional economies and value-added production at Chinese ports. Deng et al. (2013) included overall number of imports and exports in the value-added transaction construct, which is basically part of the port demand (i.e. seaborne trade) construct, which may explain the correlation.

The advantages of investing in transportation networks go beyond saving time on the road (Banister \& Berechman, 2001). According to Lakshmanan (2011), strengthened freight facilities contribute to increased trade, which is accompanied by increased labour supply and technological diffusion. Some port effect studies have found a substantial impact of port operation on regional/national economies in the US (Yochum \& Agarwal, 1987), European countries (Ferrari et al., 2010; Bottasso et al., 2013; Bottasso et al., 2014), China (Shan et al., 2014), and South Africa (Chang et al., 2014).

Due to a lack of ports, Yochum and Agarwal (1987) concluded that certain businesses in Hampton, Virginia, would suffer a substantial economic penalty. Bottasso et al. (2013) looked at the effect of ports on local jobs in 10 West European countries, using a survey of 560 regions. They noticed that every million tons of net port throughput would generate between 400 and 600 jobs in the area.

Furthermore, Bottasso et al. (2014) discovered that a ten percent rise in port throughput would result in an increase of between 6 percent and 20 percent in regional GDP and a spillover impact on neighboring regions of between 5-18 percent. Shan et al. (2014) discovered that a one percent rise in port cargo throughput will increase GDP per capita growth by 7.6 percent, and that a country's port throughput has a favourable effect on neighbouring economies. Chang et al. (2014) found that a single unit shortfall of port operation could result in a 17 percent loss in the South African economy.

As a result, the global logistics sector is extremely worried about the new international situation and the worsening international trading climate. They expect the trade war between the US and China to disrupt the global supply chain and reduce foreign trade and logistics demand.

The Financial Times (2021), Supply Chain Digital (2021), Inbound Logistics (2021), Supply Chain Brain (2021), The Asian Banker (2021), Forbes (2021), DHL (2018), Supply Chain Quarterly [50], and Logistics Management $(2019 ; 2020)$ are some of the journals and periodicals that have credible information on this matter. They see a major setback in the global logistics market's recovery. As shown by Supply Chain Digital (2021), chief executive officers (CEOs) of the world's main logistics firms expect trade wars threaten the global economy as a whole and will result in a serious recession for the logistics industry. Forbes (2021) claims that the US' "decoupling" scheme confuses the global value chain (GVC) and paralyses investment minds.

The "geopolitical bridges" that have been constructed between the G2 over the last 40 years will be destroyed. According to Logistics Management (2019), Trump's China strategy will result in major losses for the US logistics sector, as inquiries about ships in the Port of Los Angeles decreased by 25 percent year over year in October 2019, and freight volume decreased by 19.1 percent.

In this case, it's possible to wonder if the global trading and logistics sector will be able to support itself. There are fears that the global economy will face a financial crisis that will 
last longer than the recession. Furthermore, no discussion has taken into account the effect of the G2's joint actions of the US-China trade war and other countries' protectionism on world trade and logistics. The global logistics sector is not oblivious to the fact that the suspension of the Appellate Body would have a major effect on the WTO's international trade mechanism.

Therefore, from the literature review above, it is clear that Trade Protectionism, Logistic Transition, Port Composition, Port Composition, and Economic Growth deserve more academic and practical focus.

Although there has been a lot of research on this subject, the majority of it has been focused on provincial (regional) economies (He et al., 2019; Cong et al., 2020) or a particular mode of transportation (mostly seaports) (Wang \& Wang, 2019). Therefore, this study offers a valuable contribution to the literature by proposing a model that examine the effects on logistical transition, port composition and economic growth of trade protectionism

\section{Conceptual Framework}

In this research, the proposed method will be used to examined effects of trade protectionism on logistic transition, port composition, and economic growth will be based on the neoclassical economic viewpoint of transportation systems suggested by Lakshmanan (2011). Lakshmanan (2011) believes that port composition investment is exogenous, ensuring that they increase the efficiency of economic development.

Better port facilities (such as modern technology and equipment) will aid in improving a country's logistics cost (that is, greater reliability, less damage, ability to track and trace shipments, and timeliness of delivery). Improved port facilities and logistics transition will improve a country's local and global connectivity, as well as opportunities to develop markets around the world. The actualisation of these possibilities can be measured in terms of a country's overall international trade (trade protectionisms). Strengthened labour supply, increased demand, availability of alternatives, market competition, expansion of trade, and other factors all contribute to total factor productivity and Economic growth (Lakshmanan, 2011).

Competition between countries, on the other hand, is an ongoing phenomenon. Governments around the world are investing heavily in various development initiatives in order to gain a strategic edge, access to capital, and new markets in the game of being better than each other. The construction of new ports or the extension of existing ones are examples of such initiatives.

Nowadays, ports' responsibilities extend beyond container handling to provide better logistics facilities in order to satisfy the increasing demands of global supply chains. "The cost, time, and difficulty of completing import and export operations are referred to as logistics performance" (Gani, 2017). Reengineering transport routes, size, modes, or frequencies using advanced technology improves logistics efficiency (Kinra et al., 2020).

An unstructured big data approach for country logistics performance assessment in global supply chains. (International Journal of Operations \& Production Management.). Li et al., (2021) emphasized the importance of valueadded operations at ports across a variety of logistics facilities in order to gain a strategic edge, in addition to technologies and service efficiency. The standard of physical infrastructure such as roads, rail, and ports influence a country's capacity to provide complex logistics services (Luttermann et al., 2020).

In particular for landlocked countries, physical infrastructure is a significant determinant of transportation cost. As a measure of economic growth, economic performance is measured using the gross domestic product growth (GDP). This study extended the neoclassical enhanced Solow growth model, which Mankiw, Romer, and Weil (1992) first proved on the eve of the panel data system for Islam (1995). 
The Cobb-Douglas output function model was widely used to evaluate the economic growth variables, academics, and researchers to assess the impact of different measures on economic growth (Ahmad et al., 2018; Ahmad et al., 2020a; Ahmad et al., 2020b; Dabachi et al., 2020; Jakada et al., 2020.

$V_{i t}=N_{i t}^{p}\left(T_{i t} W_{i t}\right)^{1-p}$

However, the present study encompasses the equation (1) above by including Logistic Transition, Port Composition, Trade Protectionism as follows:

$\mathrm{GDP}_{i t}=(1-p) \tau_{1 i} \mathrm{LT}_{i t}+(1-p) \tau_{1 i} W_{i t}$ $+(1-p) \tau_{1 \mathrm{i}} P C_{1 i}+\omega_{i t}$

$L T_{i t}$ signposted Logistic Transition, $P C_{i t} \quad$ signposted Port; Composition; $\mathrm{TP}_{i t}$ signposted Trade Protectionism; and is an error term. Furthermore, the mediation of trade protectionism offered in eq (3) and eq (4) as follows:

$V_{i t}=\mathrm{N}_{i t}\left(T_{i t} W_{i t}\right)^{1-p} T P_{i t}=(1-p) \tau_{1 i t} L T_{i t}$

$+(1-p) \tau_{1 i} P C_{i t}+\omega_{i t}$

$\mathrm{GDP}_{i t}=(1-p) \tau_{1 i} T P_{i t}+(1-p) \tau_{1 i} L T_{i t}$

$+(1-p) \tau_{1 i} P C_{i t}+\omega_{i t}$

\section{Conclusion}

Sustained economic growth remains a top priority for policymakers and researchers, despite the fact that achieving it seems elusive due to the business global environment uncertainty and frequent adjustments. As a result, both developed and emerging countries have tried a variety of macroeconomic development policies, with differing levels of effectiveness.

In this study, the conceptual review demonstrates that improvement in trade protectionism, logistic transition, and port composition would bring the greatest benefits to the economy of a country. Trade protectionism, logistic transition, and port composition, nonetheless, has been conceptualised and evaluated in various ways, leaving its wider function in the theoretical framework of economic growth uncertain and underutilised. In addition, economic growth tends to be absent from any of the research on trade protectionism, logistic transition, and port composition.

Furthermore, this study proposes a framework which can help researchers more effectively utilise protectionism, logistic transition, and port composition and economic growth data and research. However, the effects on logistical transition, port composition and economic growth of trade protectionism should be studied in addition, using the proposed growth models.

For future research, the interplay between the port size and the category of the economy would be important. Researchers may also be considered on the comparative economic effect of the hub and gateway ports.

The studies should also look at the trade protectionism of landlocked countries and their neighbours with regard to the logistic transition, port composition and economic growth. Finally, the paper claimed that the proposed model is worthy of consideration for analysing the production process, not because it is a simple model that can be used quickly or as a synthetic method for estimating, but because of the advantages it offers. These advantages are attributed to the reason that in its generalised form, it can accommodate several inputs. It should not introduce distortions of its own in the face of market imperfections.

The ability to handle different scales of production is further enhanced by the unconstrained Cobb-Douglas function. Different econometric estimation problems, such as serial correlation, heteroscedasticity, and multicollinearity, can be effectively and efficiently treated.

It can be concluded that its critique is focused on its inflexibility, and that all other conclusions can be relaxed except for one apparent assumption. It is often said that it makes computations easier and has properties such as explicit representability, uniformity, parsimony, and versatility. It can also be sued 
to explain and resolve issues with simultaneity. It is also proposed in this paper that integrated technologies can be well expressed by it.

\section{Acknowledgements}

The authors would like to thank the reviewers for their helpful comments to improve this article.

\section{References}

Aggarwal, V., \& Evenett, S. J. (2013). A fragmenting global economy: a weakened WTO, MEGA FTAS, and Murky Protectionism (Discussion Paper No. 9781). Centre for Economic Policy Research. Retrieved from https:// repec.cepr.org/ repec/cpr/ceprdp/ DP9781.pdf

Aharonovitz, M. C. S., Vieira, J. G. V., \& Suyama, S. S. (2018). How logistics performance is affected by supply chain relationships. The international Journal of Logistics Management, 29(1), 285-307.

Ahmad, A. U., Ismail, S., Jakada, A. H., Farouq, I. S., Muhammad, A. A., Mustapha, U. A., \& Muhammad, A. (2020a). A heterogeneous relationships between urbanization, energy consumption, economic growth on environmental degradation: Panel Study of Malaysia and Selected ASEAN+ 3 Countries. Journal of Environmental Treatment Techniques, 8(1), 573-581.

Ahmad, A. U., Ismail, S., Jakada, A. H., Farouq, I. S., Muhammad, A. A., Mustapha, U. A., \& Muhammad, A. (2020b). A heterogeneous relationships between urbanization, energy consumption, economic growth on environmental degradation: Panel Study of Malaysia and Selected ASEAN+ 3 Countries. Journal of Environmental Treatment Techniques, 8(1), 573-581.
Ahmad, A. U., Loganathan, N., Streimikiene, D., \& Hassan, A. A. G. (2018). Financial instability, trade openness and energy prices on leading African countries sustainable growth. Economic Computation and Economic Cybernetics Studies and Research, 52(1), 127-142.

Aizenman, J., \& Marion, N. P. (1993). Policy uncertainty, persistence and growth. Review of international economics, 1(2), 145-163.

Alege, P. O., \& Osabuohien, E. S. (2015). Trade-exchange rate nexus in sub-saharan african countries: Evidence from panel cointegration analysis. Foreign Trade Review, 50(3), 151-167. https://doi. org/10.1177/0015732515589440

Andersen, J. E., Larch, M., \& Yotov, Y. V. (2020). Transitional growth and trade with frictions: A structural estimation framework. Economic Journal, 130(630), 1583-1607.

Arrow, K., (1962). Economic welfare and the allocation of resources for invention. The Rate and direction of inventive activity: economic and social factors the rate and direction of inventive activity: Economic and social factors. Princeton University Press, (pp. 609-626).

Aschauer, D. A., (1989). Is public expenditure productive? Journal of Monetary Economics. 23(2), 177-200

Balliauw, M., Kort, P. M., \& Zhang, A. (2019). Capacity investment decisions of two competing ports under uncertainty: A strategic real options approach. Transportation research part B: Methodological, 122, 249264.

Banister, D., \& Berechman, Y. (2001). Transport investment and the promotion of economic growth. Journal of Transport Geography, 9(3), 209-218.

Behar, A., \& Venables, A. J., (2011). Transport costs and international trade. In Palma, A.d., Lindsey, R., Quinet, E., Vickerman, R. (Eds.), A Handbook of Transport Economics. Edward Elgar Publishing 
Benedyk, I. V., \& Peeta, S. (2018). A binary probit model to analyze freight transportation decision-maker perspectives for container shipping on the Northern Sea Route. Maritime Economics \& Logistics, 20(3), 358-374.

Benhabib, J., \& Mark. M. S (1994). The role of human capital in economic development: evidence from aggregate cross-country data. Journal of Monetary Economics, 34, 2(October), 143-173.

Bottasso, A., Conti, M., Ferrari, C., Merk, O., \& Tei, A. (2013). The impact of port throughput on local employment: Evidence from a panel of European regions. Transport Policy, 27, 32-38.

Bown, C. P., \& Crowley, M. A. (2014). Emerging economies, trade policy, and macroeconomic shocks. Journal of Development Economics, 111, 261-273. https://doi.org/10.1016/j. jdeveco.2014.05.001

Briguglio, L. P., Vella, M., \& Moncada, S. (2019). Economic growth and the concept of diminishing marginal governance effect. Journal of Economic Studies.

Brox, J. A., \& Fader, C. A., (2005). Infrastructure investment and Canadian manufacturing productivity. Applied Economics, 37(11), 1247-1256.

Burtless, G. (1995). International trade and the rise in earnings inequality. Journal of economic literature, 33(2), 800-816.

Caballe, J., \& M. S., Smtos. (1993). On Endogenous Growth with Physical and Human Capita 1. Journal of Political Economy, 101, 6(December), 1042-1067.

Calderon, C., \& Serv'en, L. (2010). Infrastructure and economic development in sub-saharan africa. Journal of African Economies 19, $13-87$
Carstens, A. (2018). Global market structures and the high price of protectionism. Paper presented at The Federal Reserve Bank of Kansas City's 42nd Economic Policy Symposium. Jackson Hole, Wyoming. Retrieved from https://www.bis. org/ speeches/sp180825.htm

Castillo, C., Molina, R., Campos, A., \& Garcia-Valdecasas, J. (2020). Application of rainflow techniques to the design and operation of port infrastructure. Coastal Engineering Proceedings, (36v), 41-41.

Cavallaro, E., \& Villani, I. (2021). Real income convergence and the patterns of financial integration in the EU. The North American Journal of Economics and Finance, 56, 101337.

Çelebi, D. (2019). The role of logistics performance in promoting trade. Maritime, Economics and Logistics, Logist. 1-17

Chang, Y. T., Shin, S. H., \& Lee, P. T. W. (2014). Economic impact of port sectors on south African economy: an input-output analysis. Transport Policy, 35, 333-340.

Cheong, I., \& Tongzon, J. (2018). The economic impact of a rise in US trade protectionism on East Asia. Journal of Korea Trade, 22(3), 265-279.

Cong, L. Z., Zhang, D., Wang, M. L., Xu, H. F., \& Li, L. (2020). The role of ports in the economic development of port cities: panel evidence from China. Transport Policy, 90, 13-21.

Constantinescu, C., Mattoo, A., \& Ruta, M. (2015). The global trade slowdown: Cyclical or structural? (IMF Working Papers No. WP/15/6). Retrieved from https:// www. imf.org/external/pubs/ft/ wp/2015/wp1506. pdf

Copeland, B., Tower, E., \& Webb, M. (1989). Quota wars and tariff wars. Oxford Economic Papers 82 (October), 774-88. 
Costa, R., Dhingra, S., \& Machin, S. (2019). Trade and worker deskilling (NBER working paper No. 25919). NBER Program(s): International trade and investment. Retrieved from https:// www.nber. org/papers/w25919

Curran, L., \& Eckhardt, J. (2018). Strategic responses of trade-dependent firms to rising trade protectionism. In Würzburg International Business Forum International Business Conference 2018, (pp. 93).

Dabachi, U. M., Mahmood, S., Ahmad, A. U., Ismail, S., Farouq, I. S., Jakada, A. H., \& Kabiru, K. (2020). Energy consumption, energy price, energy intensity environmental degradation, and economic growth nexus in African OPEC countries: Evidence from simultaneous equations models. Journal of Environmental Treatment Techniques, 8(1), 403-409.

Darlington, J., Guo, Y. K., To, H. W., \& Yang, J. (1995, August). Parallel skeletons for structured composition. In Proceedings of the Fifth ACM SIGPLAN symposium on Principles and practice of parallel programming (pp. 19-28).

de Lima, D. P., Fioriolli, J. C., Padula, A. D., \& Pumi, G. (2018). The impact of Chinese imports of soybean on port infrastructure in Brazil: A study based on the concept of the "Bullwhip Effect". Journal of Commodity Markets, 9, 55-76.

de Vries, M. G. (1967). Trade and exchange policies for economic development. Finance and Development, 4(2), 111.

Deng, P., Lu, S., \& Xiao, H., (2013) Evaluation of the relevance measure between ports and regional economy using structural equation modeling. Transport Policy, 27, 123-133

DHL. (2018). The Resilience360 Annual Risk Report; DHL: Bonn, Germany.

Duzbaievna, S. M., Antoni, A., \& Yessenzhigitova, R. (2019). The impact of port transport-logistics infrastructure and lpi for economic growth: on the example of landlocked countries. Pomorstvo, 33(1), 6375 .
Eaton, J. E., Kortum, S., Neiman, B., \& Romalis, J. (2016). Trade and the global recession. American Economic Review, 106(11), 3401-3438.

Erokhin, V. (2017). Self-sufficiency versus security: How trade protectionism challenges the sustainability of the food supply in Russia. Sustainability, 9(11), 1939.

Ferrari, C., Percoco, M., Tedeschi A. (2010) Ports and local development: evidence from Italy. International Journal of Transport Economics, 37(1), 9-30

Financial times, US-China trade war Prompts Rethink on supply chains (year). Retrieved April 18, 2021, from https: //www. ft.com/content/03e4f016-aa9a-11e8-94bdcba20d67390c

Fink, G. (1999). New protectionism in Central Europe. Exchange rate adjustment, customs tariffs and non-tariff measures.

Forbes. Beyond 'Decoupling': How China will reshape global trade in 2020. Retrieved April 18, 2021, from https://www.forbes. com/sites/siminamistreanu/2019/12/03/ beyond-decoupling-how-china-willreshapeglobal-trade-in-2020/\#77973f0c65b7

Fosu, A., Getachew, Y., \& Ziesemer, T. (2012). Optimal public investment, growth and consumption: Evidence from African countries. Brooks World Poverty Institute Working Paper, (pp. 164).

Fu, X., Tsui, K., Sampaio, B., \& Tan, d.t.w. (2018). The impacts of airport activities on regional economy-An empirical analysis of New Zealand, 18-08. ITLS-WP-.

Gani, A. (2017). The logistics performance effect in international trade. The Asian Journal of Shipping and Logistics, 33(4), 279-288.

Gokcekus, O., \& Tower, E. (1989). Does trade liberalization benefit old and young alike? Review of International Economics, 6 (February), 50-58. 
Gripaios, P., \& Gripaios, R. (1995) The impact of a port on its local economy: The case of Plymouth. Maritime Policy Management, 22(1), 13-23

Grundke, R., \& Moser, C. (2019). Hidden protectionism? Evidence from non-tariff barriers to trade in the United States. Journal of International Economics, 117, 143-157. https://doi.org/10.1016/j. jinteco.2018.12.007

Gygli, S., Haelg, F., Potrafke, N., \& Sturm, J.-E. (2019). The KOF globalization index - revisited. Review of International Organizations, 14(3), 543-574.

Halaszovich, T.F., \& Kinra, A. (2018). The impact of distance, national transportation systems and logistics performance on fdi and international trade patterns: Results from Asian global value chains. transport policy.

Hammes, G., De Souza, E. D., Rodriguez, C. M. T., Millan, R. H. R., \& Herazo, J. C. M. (2020). Evaluation of the reverse logistics performance in civil construction. Journal of Cleaner Production, 248, 119212.

Hathaway, O. A. (1998). Positive feedback: the impact of trade liberalization on industry demands for protection. International Organization, 52(3), 575-612.

He, D., Yin, Q., Zheng, M., \& Gao, P. (2019). Transport and regional economic integration: evidence from the Chang-ZhuTan region in China. Transport policy, 79, 193-203.

Inbound Logistics. (2021) Tariffs Sting U.S. Supply Chains. Retrieved April 17, 2021, from https://www.inboundlogistics.com/ cms/article/tariffs-sting-us-supply-chains/

IRC. (2016). Understanding the weakness in global trade - What is the new normal? (ECB Occasional Paper, No. 178). European Central Bank (ECB), IRC Trade Task Force. Retrieved from https:// www.ecb.europa.eu/ pub/pdf/ scpops/ecbop178.en.pdf
Islam, N., (1995) Growth empirics: a panel data approach. The Quarterly Journal of Economics, 1127-1170.

Jaffee, D. (2019). Neoliberal urbanism as Strategic Coupling to global chains: Port infrastructure and the role of economic impact studies. Environment and Planning C: Politics and Space, 37(1), 119-136.

Jakada, A. H., Mahmood, S., Ahmad, A. U., \& Bambale, S. A. (2020b). Heterogeneous moderating influence of economic growth on financial development and environmental quality in Africa. Journal of Critical Reviews, 7(14), 127-133.

Jung B-M(2011) Economic contribution of ports to the local economies in Korea. The Asian Journal Shipping and Logistics, 27(1), 1-30

Khan, S. A. R., Jian, C., Zhang, Y., Golpîra, H., Kumar, A., \& Sharif, A. (2019). Environmental, social and economic growth indicators spur logistics performance: From the perspective of South Asian Association for Regional Cooperation countries. Journal of Cleaner Production, 214, 1011-1023.

Kinra, A., Hald, K. S., Mukkamala, R. R., \& Vatrapu, R. (2020). An unstructured big data approach for country logistics performance assessment in global supply chains. International Journal of Operations \& Production management, 40(4), 439-458.

Kinsey, J. (1981). The economic impact of the port of Liverpool on the economy of Merseyside - using a multiplier approach. Geoforum, 12(4), 331-347

Kinzius, L., Sandkamp, A., \& Yalcin, E. (2019). Trade protection and the role of non-tariff barriers. Review of World Economics, 155, 603-643. https://doi.org/10.1007/ s10290019-00341-6

Kodongo, O., \& Ojah, K. (2016). Does infrastructure really explain economic growth in SubSaharan Africa? Review of Development Finance, 6(2), 105-125. 
Kravets, Y. D., Shuvalov, D. V., \& Yermoshin, N. A. (2021). Transportation and logistics system for preparing areas to unload material resources in the absence of port infrastructure, IOP Conference Series: Materials Science and Engineering (Vol. 1047, No. 1, pp. 012016). IOP Publishing.

Krueger, A. O. (1974). The political economy of the rent seeking society. American Economic Review, 64(June), 291-303.

Krueger, A.O. (1983). Trade and employment in developing countries: Volume 3 Synthesis and Conclusions. Chicago: University of Chicago Press.

Kus, tepeli, Y., Gülcan, Y., \& Akgüngor, “ S., (2012). Transportation infrastructure investment, growth and international trade in Turkey. Applied Economics, 44(20), 2619-2629.

Lai, K.-H., Pang, Y., Wong, C.W., Lun, Y.V., \& Ng, Y. E. (2019). Are trade and transport logistics activities mutually reinforcing? Some empirical evidences from ASEAN countries. Journal of Shipping and Trade, 4 (1), 2.

Lakshmanan, T. (2011) The broader economic consequences of transport infrastructure investments. Journal Transport Geography, 19(1), 1-12

Lall, S. V. (2007). Infrastructure and regional growth, growth dynamics and policy relevance for India. The Annals of Regional Science, 41(3), 581-599.

Lee, P. T. W., Lam, J. S. L., Lin, C. W., Hu, K. C., $\&$ Cheong, I. (2018). Developing the fifthgeneration port concept model: an empirical test. The International Journal of Logistics Management, 29(3), 1098-1120.

Lehmann, S. \& O'Rourke, K. H. (2011). The structure of protection and growth in the late nineteenth century. Review of Economics and Statistics, 93(2), 606-616.
Lewis, L. T., \& Monarch, R. (2016). Causes of the global trade slowdown (IFDP Working Papers, No. 2016-11-10). Board of Governors of the Federal Reserve System. https://doi.org/10.17016/2573- 2129.25

Li,C., \& Whalley, J. (2021). Trade protectionismand US manufacturing employment. Economic Modelling, 96, 353-361.

Li, Q., Yan, R., Zhang, L., \& Yan, B. (2021). Empirical study on improving international dry port competitiveness based on logistics supply chain integration: evidence from China. The International Journal of Logistics Management. https://doi.org/10.1108/ IJLM-06-2020-0256

Lin, H., \& Qixiang, W. (2020). Exploring the Mediation Effect of Logistics Performance on Economic Growth. Solid State Technology, 63(4), 5858-5869.

Liu, M. (2020). Research on Port Infrastructure, Port Efficiency and Urban Trade Development. Journal of Coastal Research, 115(SI), 220-222.

Logistics Management. (2021b). Lose-lose' trade war threatens 1.5 million jobs, \$186 billion in economic activity, new study shows. Retrieved April 18, 2021, from https://www. logisticsmgmt.com/article/lose_lose_trade war_threatens_1.5_million_jobs_186_billion_in_economic_acti

Logistics Management. (2021). Ocean carrier trends: Containing capacity while remaining poised for Growth. Retrieved April 18, 2021, from https://www.logisticsmgmt.com/ article/ocean_carrier_trends_containing capacity_while__remaining_poised_for growth

Longaray, A., Ensslin, L., Ensslin, S., Alves, G., Dutra, A., \& Munhoz, P. (2018). Using MCDA to evaluate the performance of the logistics process in public hospitals: the case of a Brazilian teaching hospital. International Transactions in Operational Research, 25(1), 133-156. 
Lucas, R., E., Jr. (1988). "On the Mechanics of Economic Development , "Journal of Monetatary Economics, 22, 1(July), 3A2.

Luttermann, S., Kotzab, H., \& Halaszovich, T. (2020). The impact of logistics performance on exports, imports and foreign direct investment. World Review of Intermodal Transportation Research, 9(1), 27-46.

Malthus, Thomas R. (1798). An Essay on the Principle of Population, London, W. Pickering, 1986.

Maparu, T. S., \& Mazumder, T. N. (2017). Transport infrastructure, economic development and urbanization in India (1990-2011): is there any causal relationship? Transport Research. Policy Practice, 100, 319-336

Markusen, J. R., Melvin, J.R., Kaempfer, W.H. and Maskus, K.E. (1995). International trade: Theory and evidence. Boston: McGraw-Hill.

Marzi, B. (1998). Information support to transport-logistic infrastructure in the port of Koper. Promet-Traffic \& Transportation, 10(56), 315-318.

Michaels, R. J. (1999). The governance of transmission operators. Energy Logistics, 20, 233.

Miller, N. J., \& Tsoukis, C. (2001). On the optimality of public capital for long-run economic growth: Evidence from panel data. Applied Economics 33(9), 1117-1129.

Moons, K., Waeyenbergh, G., \& Pintelon, L. (2019). Measuring the logistics performance of internal hospital supply chains-Aliterature study. Omega, 82, 205217.

Morgan, T. R., Tokman, M., Richey, R. G., \& Defee, C. (2018). Resource commitment and sustainability: A reverse logistics performance process model. International Journal of Physical Distribution \& Logistics Management, 48(2), 164-184.
Munim, Z. H., \& Schramm, H. J. (2018). The impacts of port infrastructure and logistics performance on economic growth: The mediating role of seaborne trade. Journal of Shipping and Trade, 3(1), 1-19.

Nader, R., Greider, W., Atwood, M., Choate, P., Shiva, V., Ritchie, M., \& Heredia, C. (1993). The case against" free trade": GATT, NAFTA, and the globalization of corporate power (Vol. 49). North Atlantic Books.

Nam, C. H. (1993). Protectionist US Trade Policy and Korean Exports. In Trade and protectionism (pp. 183-222). University of Chicago Press.

Nelson, R.R., \& Edmund, S.P. Phelps (1966). "Investment in Humans, Technological Diffusion, and Economic Growth," American Economic Review, 56, 2(May), 69-75.

Norgaard, R. B. (1992). Sustainability and the economics of assuring assets for future generations (Vol. 832). World Bank Publications.

Ojo, A. T., \& Alege, P. O. (2014). Exchange Rate Fluctuations and Macroeconomic Performance in Sub-Saharan Africa: A Dynamic Panel Cointegration Analysis. Asian Economic and Social Society, 4(11), 1573-1591. Retrieved from http://eprints.covenantuniversity. edu. ng/3996/1/EXCHANGE\%20 RATE\%20 FLUCTUATIONS\%20 AND.pdf

Olabisi, M., Tschirley, D. L., Nyange, D., \& Awokuse, T. (2021). Does trade protectionism promote domestic food security? Evidence from Tanzanian edible oil imports. Global Food Security, 28, 100470.

Osabuohien, E. S., Beecroft, I., \& Efobi, U. R. (2018). Global trade and trade protection in a globalized world. Transnational Corporations Review, 10(1), 43-52. https:// doi.org/10.1080/19186444. 2018.1436650 
Park, S. C. (2018). U.S. Protectionism and Trade Imbalance between the U.S. and Northeast Asian Countries. International Organisations Research Journal, 13(2), 76100. https://doi. org/10.17323/1996-78452018- 02-05

Park, S. C. (2019). Trade Protectionism as the Achilles Heel of International Cooperation and Countermeasures Focused on the EUJapan FTA. International Organisations Research Journal, 14(2), 191-222.

Petrakis, P. E. (2020). Theoretical Approaches to Economic Growth and Development. Springer Books.

Ramani, K. V. (1996). An interactive simulation model for the logistics planning of container operations in seaports. Simulation, 66(5), 291-300.

Ricardo, D. (1817). On the Principles of Political Economy and Taxation, P. Sraffa, ed., Cambridge, Cambridge University Press, 1951.

Roll, Y., \& Hayuth, Y. E. H. U. D. A. (1993). Port performance comparison applying data envelopment analysis (DEA). Maritime policy and Management, 20(2), 153-161.

Schularick, M. \& Solomou, S. (2011). Tariffs and economic growth in the first era of globalization. Journal of Economic Growth, 16, 33-70.

Shan, J., Yu, M., \& Lee, C. Y. (2014). An empirical investigation of the seaport's economic impact: evidence from major ports in China. Transport Research Part E: Logistics and Transportation Review, 69, 41-53.

Shao, W. M. (1995). Is There No Business Like Show Business-Free Trade and Cultural Protectionism. Yale Journal of International Law, 20, 105.
Supply Chain Brain. (2021). Impact of the USChina Trade War on Global Supply Chains. Retrieved April 18, 2021, from https://www. supplychainbrain.com/articles/30554-impact-of-the-us-china-trade-war-on-globalsupply-chains? $\mathrm{v}=$ preview

Supply Chain Digital. (2021). Turbulent Times in 2019: The Year of the Supply Chain. Retrieved April 17, 2021, from https://www. supplychaindigital.com/supply-chain-management/turbulent-times-2019-year-supplychain

Supply Chain Quarterly. (2019). The Top 10 Supply Chain Risks of 2019: Second Quarter; CSCMP: Massachusetts, MA, USA, 2019.

Sykes, A. O. (1999). Regulatory protectionism and the law of international trade. The University of Chicago Law Review, 1-46.

Taljaard, S., Slinger, J. H., Arabi, S., Weerts, S. P., \& Vreugdenhil, H. (2021). The natural environment in port development: A 'green handbrake'or an equal partner?. Ocean \& Coastal Management, 199, 105390.

The Asian Banker. (2021) US-China Trade War Highlights Shifting Global Terrain for Financial Services. Retrieved April 18, 2021, from http://www.theasianbanker. com/updates-and-articles/us-china-tradewar-highlights-shifting-globalterrain-forfinancial-services

Trachtman, J. P. (1993). International regulatory competition, externalization, and jurisdiction. Harvard International Law Journal, 34, 47.

Tsapi, V. (2020, April). Flow Management Tools and Techniques for Logistics Performance: An Application to the Logistics Service Sector in Cameroon. In Dynamics in Logistics: Proceedings of the 7th International Conference LDIC 2020, Bremen, Germany (pp. 148). Springer Nature. 
UNCTAD. (2020) Review of maritime transport. United Nations conference on trade and development. United Nations Publication, Geneva.

Wang, M. (2018). Impacts of supply chain uncertainty and risk on the logistics performance. Asia Pacific Journal of Marketing and Logistics, 30(3), 689-704.

Wang, Q., Cheng, F., Xue, J., Xiao, N., \& Wu, H. (2020). Bacterial community composition and diversity in the ballast water of container ships arriving at Yangshan Port, Shanghai, China. Marine Pollution Bulletin, 160, 111640 .

Wang, Y., \& Wang, N., (2019). The role of the port industry in China's national economy: an input-output analysis. Transport Policy, $78,1-7$.

Wessel, J., (2019). Evaluating the transportmode-specific trade effects of different transport infrastructure types. Transport Policy, 78, 42-57
Williams Iii, R. C. (1999). Revisiting the cost of protectionism:: The role of tax distortions in the labor market. Journal of International Economics, 47(2), 429-447.

Yochum G. R., \& Agarwal V. B. (1987) Economic impact of a port on a regional economy: note. Growth Change, 18(3),7487.

Yudhistira, M.H., \& Sofiyandi, Y.(2018). Seaport status, port access, and regional economic development in Indonesia. Maritime Economics \& Logistics, 20(4), 549-568.

Zhao, C., Wang, Y., Gong, Y., Brown, S., \& Li, R. (2021). The evolution of the port network along the Maritime Silk Road: From a sustainable development perspective. Marine Policy, 126, 104426.

Ziesemer, T. (2021). Labour-augmenting technical change data for alternative elasticities of substitution, growth, slowdown, and distribution dynamics (No. 2021-003). United Nations University-Maastricht Economic and Social Research Institute on Innovation and Technology (MERIT). 